\title{
COVID-19 stigmatization: A devil and a deep blue sea
}

\author{
Kehinde K. Kanmodi ${ }^{1,2,3}$, Precious A. Kanmodi ${ }^{2,3}$
}

\section{AFFILIATION}

1 Department of Political Science, National Open University of Nigeria, Birnin Kebbi, Nigeria

2 Cephas Health Research Initiative Inc, Ibadan, Nigeria

3 Mental and Oral Health Development Organization, Birnin Kebbi, Nigeria

\section{CORRESPONDENCE TO}

Kehinda K. Kanmodi. Department of Political Science, National Open University of Nigeria, Jega, Birnin-Kebbi Road, Birnin Kebbi, Nigeria. E-mail: kanmodikehinde@yahoo.com

\section{KEYWORDS}

COVID-19, coronavirus, stigma, stigmatization, public health, global health

Received: 24 April 2020, Accepted: 28 April 2020

\section{Dear Editor,}

COVID-19, is an on-going pandemic that started as an outbreak in December 2019, in Wuhan City, China ${ }^{1}$. The outbreak was epidemiologically linked to a wet animal whole sale market in Wuhan City, China ${ }^{1}$. As at 22 April 2020, almost 2.5 million cases of COVID-19 had been reported with more than 160000 deaths, worldwide ${ }^{2}$. Also, as of this same day (22 April 2020), the US has been the epicentre of COVID-19 with 828441 cases recorded and 46379 associated deaths ${ }^{3}$.

So far, there have been serious global concerns about issues of stigmatization associated with COVID-19,5. According to a recent news report on COVID-19, some Africans residing in Guangzhou, China, were stigmatized because they were presumed to be COVID-19 infectors ${ }^{4}$. COVID-19 in itself is not a death sentence, but a viral infection that has the potential of causing life-threatening conditions ${ }^{6}$. However, due to fear, bias, and/or ignorance, people tend to stigmatize people suspected or confirmed to have COVID-194.

COVID-19 stigmatization is a global issue that requires public health attention ${ }^{7}$. This is so because such stigmatization can drive people to hide the illness due to fears of being discriminated against; preventing them to seek medical care early or discouraging them from adopting healthy behaviours ${ }^{7}$. Hence, COVID-19 stigmatization may also directly or indirectly increase the spread of the disease.

So that the protection and safety of people infected with COVID-19 can be assured, policymakers of each nation should also take into account measures to protect patients from stigmatization.

\section{REFERENCES}

1. Mackenzie JS, Smith DW. COVID-19: a novel zoonotic disease caused by a coronavirus from China: what we know and what we don't. Microbiol Aust. 2020;41(1):45. doi:10.1071/MA20013

2. World Health Organization. WHO Director-General's opening remarks at the media briefing on COVID-19. https://www. who.int/dg/speeches/detail/who-director-general-sopening-remarks-at-the-media-briefing-on-covid-19--22april-2020. Published April 22, 2020. Accessed April 24, 2020.

3. Centre for Disease Control and Prevention. Coronavirus Disease 2019 (COVID-19): Cases in the U.S. https://www. cdc.gov/coronavirus/2019-ncov/cases-updates/cases-inus.html. Updated April 23, 2020. Accessed April 24, 2020.

4. BBC. Covid-19 stigma: Chinese hotels \& apartments don pursue Africans comot from dia property for fear of coronavirus. https://www.bbc.com/pidgin/tori-52211995. Published April 8, 2020. Accessed April 24, 2020.

5. International Organization for Migration. COVID-19 Analytical Snapshot \#6: Stigmatization \& discrimination. https://www.iom.int/sites/default/files/our_work/ICP/ MPR/covid-19_analytical_snapshot_6_-_stigmatization_and_ discrimination.pdf. Published April 2, 2020. Accessed April 24, 2020.

6. Li T, Lu H, Zhang W. Clinical observation and management of COVID-19 patients. Emerg Microbes Infect. 2020;9(1):687690. doi:10.1080/22221751.2020.1741327

7. International Federation of Red Cross, UNICEF, World Health Organization. Social Stigma associated with COVID-19. https://www.unicef.org/media/65931/file/Social\%20 
stigma $\% 20$ associated $\% 20$ with $\% 20$ the $\% 20$ coronavirus $\% 20$ disease\%202019\%20(COVID-19).pdf. Published February 24, 2020. Accessed April 24, 2020.

CONFLICTS OF INTEREST

The authors have completed and submitted the ICMJE Form for Disclosure of Potential Conflicts of Interest and none was reported.
PROVENANCE AND PEER REVIEW

Not commissioned; internally peer reviewed.

FUNDING

There was no source of funding for this research. 